\title{
The genera Bernardia Houst. ex Mill. and Tragia L. (Euphorbiaceae, Acalyphoideae) in Northeastern Brazil
}

\author{
Mirane de Oliveira Santos ${ }^{1}$, Wesley Patrício Freire de Sá Cordeiro ${ }^{2}$, Margareth Ferreira de Sales ${ }^{2} \&$ \\ Juliana Santos Silva ${ }^{1,2 *}$ \\ ${ }^{1}$ Universidade do Estado da Bahia, Departamento de Educação, Programa de Pós-Graduação em \\ Biodiversidade Vegetal, Paulo Afonso, BA, Brasil \\ ${ }^{2}$ Universidade Federal Rural de Pernambuco, Departamento de Biologia, Programa de Pós-graduação em \\ Botânica, Recife, PE, Brasil \\ *Corresponding author: Juliana Santos Silva,e-mail: jussilva@uneb.br
}

SANTOS, M.O., CORDEIRO, W.P.F.S., SALES, M.F., SANTOS SILVA, J. The genera Bernardia Houst. ex Mill. and Tragia L. (Euphorbiaceae, Acalyphoideae) in Northeastern Brazil. Biota Neotropica. 19(3): e20180592. http://dx.doi.org/10.1590/1676-0611-BN-2018-0592

\begin{abstract}
Bernardia and Tragia are genera of the subfamily Acalyphoideae, with species occurring in tropical and subtropical regions. Studies concerning those genera are scarce in Brazil, including Northeastern Brazil. The present study was designed to study the taxonomy of species occurring there, and provides illustrations, keys, descriptions, and comments concerning taxonomic affinities, as well as information concerning their geographic distributions and environmental preferences. A total of 13 species were encountered, eight of Bernardia and five of Tragia. Of those, B. hamadryadica and T. cearensis are endemic to Northeastern Brazil and B. celastrinea, B. pulchella, and $T$. chlorocaulon are new records for the region. The two genera occur in moist Atlantic forests, in forest borders, and anthropically impacted areas. New occurrences were recorded in all of the states, totaling 21 new records. The principal diagnostic characters for distinguish were: the sexuality of the plant (monoecious or dioecious), the presence of foliar glands, the types of inflorescence and trichomes, and the numbers of stamens. Among the 13 species encountered, six are illustrated here for the first time.
\end{abstract}

Keywords: Bernardieae, Floristic, new occurrences, Plukenetieae, Tragiinae.

\section{Os gêneros Bernardia Houst. ex Mill. e Tragia L. (Euphorbiaceae, Acalyphoideae) na região Nordeste do Brasil}

Resumo: Bernardia e Tragia são gêneros da subfamília Acalyphoideae com espécies ocorrendo nas regiões tropicais e subtropicais. Estudos referenciando especificamente esses gêneros são escassos no Brasil, incluindo o Nordeste brasileiro. Portanto, o presente trabalho teve como objetivo realizar o estudo taxonômico das espécies ocorrentes na região Nordeste, fornecendo ilustrações, chave de identificação, descrições e breves comentários sobre afinidades taxonômicas, além de dados de distribuição geográfica e ambiente preferencial das espécies. Um total de 13 espécies foi registrado, sendo oito de Bernardia e cinco de Tragia. Destas, B. hamadryadica e T. cearensis são endêmicas do Nordeste e $B$. celastrinea, $B$. pulchella e T. chlorocaulon são novos registros para a região. Ambos os gêneros predominam em vegetações de Mata Atlântica em bordas de mata e áreas antropizadas. Novas ocorrências foram verificadas em todos os estados, totalizando 21 novos registros. Os caracteres diagnósticos para distinguir as espécies foram a sexualidade da planta (monoicia ou diocia), presença de glândulas foliares, tipo de inflorescência e tricoma, e número de estames. Dentre as 13 espécies encontradas, seis delas foram ilustradas pela primeira vez. Palavras-chave: Bernardieae, Florística, novas ocorrências, Plukenetieae, Tragiinae. 


\section{Introduction}

The family Euphorbiaceae is one of the most diverse families of Malpighiales, with 6,300 species and 219 genera, occurring predominantly in tropical and subtropical regions (APG IV 2016, Wurdack et al. 2005, Wurdack \& Davis 2009). In Brazil, ca. 950 species and 64 genera occur, and they are most common in the Cerrado (Flora do Brasil 2020 under construction). Euphorbiaceae s.s. was restricted to the uniovulate subfamilies Acalyphoideae Beilschm. (20 tribes), Cheilosoideae (Müll. Arg.) K. Wurdack \& Petra Hoffm. (1), Crotonoideae Burmeist. (12), Euphorbioideae Beilschm. (5) and Peroideae Baill. ex Hassk. (4) (Wurdack et al. 2005). However, subfamilies Cheilosoideae and Peroideae were excluded in the current concept (Wurdack \& Davis 2009).

Acalyphoideae is the largest and most complex subfamily of Euphorbiaceae, comprising 99 genera and 3,000 species (Webster 2014). It is separated from the other subfamilies by the absence of milky latex; laticifers usually absent, or if present, non-articulate; and pollen grains binucleate, but other characteristics are also useful. The absence of petals on the staminate and pistillate flowers is common; only a few taxa (e.g., Chrozophora Necker ex A. Juss. and Ditaxis Vahl ex A. Juss.) have petals at least in staminate flowers. Most seeds do not have a caruncle, and the pollen does not show the Croton pattern of sexine ornamentation: tectate with triangular processes frequently forming continuous arrays (Webster 2014, Gillespie \& Ambruster 1997). Bernardia Houst. ex Mill. and Tragia L. are among the most diverse genera, with 68 and ca. 150 species, respectively (Cardinal-McTeague \& Gillespie 2016, Govaerts et al. 2000).

Bernardia is the largest genus of tribe Bernardieae Webster and it has a neotropical distribution, with Brazil and Mexico being the main centers of diversity (Webster 1994, Govaerts et al. 2000, Cervantes et al. 2009). Pax \& Hoffmann (1914) recognized seven sections for the genus [Bernardia sect. Tyria (Klotzsch) Müll. Arg., B. sect. Alevia (Baill.) Müll. Arg., B. sect. Polyboea (Klotzsch) Müll. Arg., B. sect. Phyllopassaea Müll. Arg., B. sect. Crassifoliae Pax et K. Hoffm., B. sect. Passaea (Baill.) Müll. Arg., and B. sect. Traganthus (Klotzsch) Müll. Arg.] based on characteristics such as habit, indumentum and leaf venation patterns, along with stamen, receptacle, and style morphology.

Bernardia is represented in Brazil by 22 species that are distributed mostly in the Southeast, in areas of Cerrado (neotropical savanna) vegetation and Atlantic Forest. Seven species occur in Northeastern Brazil [Bernardia axillaris (Spreng.) Müll. Arg., B. gambosa Müll. Arg., B. hamadryadica J.F. Carrión \& Cordeiro, B. major (Müll.Arg.) Pax \& K.Hoffm., B. scabra Müll. Arg., B. sidoides (Klotzsch) Müll. Arg., and B. tamanduana (Baill.) Müll. Arg.] (Carrión 2018).

Tragia is the largest genus of the tribe Plukenetieae (Benth.) Hutch. and subtribe Tragiinae Webster (Cardinal-McTeague \& Gillespie 2016). It has a pantropical distribution, with its principal centers of diversity in the Americas and Africa (Webster 2014). Pax \& Hoffmann (1919) initially recognized nine sections for the genus [T. sect. Zuckertia (Baill.) Müll. Arg., T. sect. Bia (Klotzsch) Müll. Arg., T. sect. Leucandra (Klotzsch) Müll. Arg., T. sect. Eutragia Müll. Arg., T. sect. Ratiga Müll. Arg., T. sect. Agirta Baill., T. sect. Ctenomeria (Harv.) Benth. T. sect. Tagira Müll. Arg., and T. sect. Lassia (Baill.) Müll. Arg.] based on sepal morphology, presence of a glandular disk, filament and anther morphology, and the number of stamens. A new section ( $T$. sect. Monadelphae L.J. Gillespie) was added later (Gillespie 1994a), and some of the existing sections ( $T$. sect. Bia, T. sect. Ctenomeria, $T$. sect. Zuckertia) were elevated to the category of genus (Webster 2007, 2014, Medeiros et al. 2013).

Sixteen species of Tragia occur in Brazil, distributed throughout the country, although more common in the Atlantic Forest. The genus is represented by five species in Northeastern Brazil (Tragia bahiensis Müll. Arg., T. cearensis Pax \& K. Hoffm., T. cuneata Müll. Arg., T. friesii Pax \& K. Hoffm. and T. volubilis L.) (Flora do Brasil 2020 under construction).

The two genera can be distinguished by their habit, breeding system (monoecious or dioecious), types of trichomes and inflorescence. Bernardia species are monoecious or dioecious shrubs, with simple or stellate trichomes, and unisexual inflorescences (Webster \& Burch 1967, Webster 1994). Tragia species are herbaceous vines, monoecious, with simple, urticating trichomes and capitate glands, and bisexual inflorescences (Urtecho 1996, Cardinal-McTeague \& Gillespie 2016).

In spite of the great richness and morphological diversity of the species of Euphorbiaceae in Brazil, studies of the genera Bernardia and Tragia have been very rare there. The treatment of Euphorbiaceae published by Müller Argoviensis (1874) in the Flora brasiliensis comprised 16 species of Bernardia and 22 of Tragia. There are records of species of both genera in floristic surveys undertaken in the Serra do Cipó in Minas Gerais State (Cordeiro 1992), areas of inselbergs in Milagres (Carneiro et al. 2002), sandy caatingas both in Bahia State (Sátiro \& Roque 2008), and in caatinga vegetation in Porto Folha, Sergipe State (Oliveira 2013). Carrión et al. (2017) recently described Bernardia hamadryadica J.F. Carrión \& Cordeiro for the Chapada Diamantina (Bahia), the first new species of that genus for South America in 40 years.

Despite recent progress, there has been little research on those two genera in Northeastern Brazil, and few collections are encountered in regional herbaria, moreover there is a lack of taxonomists specialized in these groups, consequently many specimens remain unidentified or misidentified in herbaria. In that context, the present work examined the taxonomy of the species of Bernardia and Tragia occurring in Northeastern Brazil to contribute to a better understanding of those genera, provide keys, morphological descriptions, illustrations, and data concerning their geographic distributions and preferred habitats, to amplify our knowledge of that region's vegetation and to serve as a basis for future taxonomic revisions.

\section{Materials and Methods}

\section{Study area}

Northeastern Brazil is the third largest geographic area in Brazil, covering approximately $1,540,827 \mathrm{~km}^{2}$ (Schneeberger \& Farago 2003). The vegetation there is predominantly caatinga (fully deciduous, thorny, xeric vegetation) but, depending on the landscape and elevation, significant areas of forests (ombrophilous and seasonal), savannas (cerrado), campos rupestres, dunes, and mangrove swamps are also present (Barbosa et al. 2006).

Northeastern Brazil is known for its hot, sunny weather, with mean temperatures between $20^{\circ}$ and $28^{\circ} \mathrm{C}$. It is divided into four sub-regions: the Mid-North, which corresponds to the transition between the Amazon region and the dry sertão (also known as the Mata do Cocais); the sertão 
itself, where the climate is semiarid and the vegetation is caatinga; the agreste, which corresponds to the transition between the sertão and the forest zone; and the forest zone, characterized by abundant rainfall (Vieira et al. 2008).

\section{Taxonomic study}

The present study was based on field collections made between April/2016 and December/2017, concentrated principally in the states of Bahia, Paraíba, Pernambuco, and Sergipe (where the largest numbers of species have been recorded). We also examined approximately 1,000 specimens of Bernardia and Tragia deposited in the principal herbaria in the northeastern region (ALCB, CEPEC, EAC, , HRB, HUEFS, HUNEB, IAN, IPA, JPB, PEUFR, UFP, and HESBRA and HST of Federal Rural of Pernambuco), as well as in a herbarium in southeastern Brazil (RB); acronyms according to Thiers 2018 (continuously updated). Protologues of all of the species studied were consulted, as well as digitized specimens (especially of the type collections deposited in $\mathrm{K}$ [https://www.kew.org/]), NYBG (http://sweetgum.nybg.org/science/ vh/), P (http://www.mnhn.fr/fr/collections/ensembles-collections/ botanique), and other herbaria material available online on species Link (http://www.splink.org.br).

The species were identified using analytical keys from classic publications, regional floras, and taxonomic revisions (e.g., Pax \& Hoffmann 1914, 1919, Múlgura \& Sanguinetti 1989, Gillespie 1993, 1994a, Urtecho 1996, Gillespie \& Armbruster 1997), or by comparisons with protologues and type collections. Standardization of the terminology for the vegetative and reproductive structures of the species was based on Harris \& Harris (1994). Croizat (1943) was adopted for the shapes of the foliar basilaminar glands.

Information concerning the geographic distributions of the taxa were ascertained from the aforementioned sources, the site of the Flora do Brasil (http://www.floradobrasil.jbrj.gov.br), as well as observations of the species in the study area; data concerning flowering, fruiting, vegetation types, and soils were extracted from the herbarium specimen labels.

We opted not to treat infraspecific categories for Bernardia and Tragia because there are many gaps in the available information and ongoing discussions concerning their correct identifications and infraspecific classifications.

\section{Results and Discussion}

Thirteen species were recorded in the study area, eight of Bernardia and five of Tragia, representing 35\% of the Brazilian species of Bernardia and $31 \%$ of Tragia. Among the species recorded, seven are endemic to Brazil (Bernardia axillaris, B. celastrinea (Baill.) Müll. Arg., B. gambosa, B. hamadryadica, B. scabra, B. tamanduana and T cearensis) and occur in almost all regions of the country. Bernardia hamadryadica and Tragia cearensis are endemic to Northeastern Brazil. The non-endemic species are found also in Argentina (T. bahiensis, T. volubilis), Bolivia (B. pulchella [Baill.] Müll. Arg., T. chlorocaulon Baill., T. friesii), and Mexico (B. sidoides). Tragia cuneata and B. major were cited for Northeastern Brazil in Flora do Brasil 2020, but these species were not found in the herbaria. Specimens previously identified as T. cuneata are in fact T. volubilis (e.g., Santos, T.S. 423) or other genera (e.g., Bia Klotzsch and Caperonia A.St.-Hil.). Bernardia celastrinea, B. pulchella, and T. chlorocaulon are cited here for the first time for that region, thereby increasing the number of species cited in Northeastern for Bernardia from seven to nine, and for Tragia from four to five. The genus Bernardia is most diverse in the state of Bahia (eight species) and Tragia is more numerous in the state of Ceará (five species). Tragia volubilis stands out as having the widest distribution, found in almost all states in Northeastern Brazil; Bernardia sidoides likewise occurs in almost all of those states, with the exception of Maranhão.

New records were encountered for almost all of the states in that region, with 21 new occurrences, such as: Bernardia axillaris for Paraíba; B. celastrinea and B. pulchella for Bahia; T. cearensis for Alagoas, Paraíba, Rio Grande do Norte and Sergipe; T. chlorocaulon for Maranhão; T. friesii for Alagoas, Bahia, Ceará, Sergipe and Paraíba; and T. volubilis for Alagoas, Ceará, Maranhão, Paraíba, Pernambuco, Piauí, Rio Grande do Norte, and Sergipe. New records were encountered principally in caatinga and atlantic forest vegetation, with some occurrences also in cerrado ( $T$. bahiensis, T. chlorocaulon, and T. volubilis), on different types of soils (sandy, clayey, rocky), and in areas with granite or limestone outcrops, being most frequent in open areas such as forest edges and anthropogenically impacted environments at elevations between 22 and 1,010 $\mathrm{m}$ above sea level elevation.

The significant number of new records may be related to a previous lack of research on these two genera in Northeastern Brazil, the few collections encountered in regional herbarium and the lack of specialized taxonomists in this group. This shows the importance of this kind of research and the need for new studies in both genera.

The principal diagnostic characteristics of the taxa of Bernardia include their habit, the presence or absence of basilaminar glands (when present in different numbers and locations, with some species showing paired glands), phyllotaxy, and the type of the staminate inflorescence. Tragia species can be distinguished by their types of trichomes, the number of stamens, and the length of the pedicel of the fruit.

Most of the species of Bernardia analysed in the study area belong to section Polyboea, with the exception of B. sidoides (B. sect. Traganthus) and B. gambosa (unknown section; Cervantes et al. 2009). All of the species of Tragia treated belong to section Tragia (Múlgura \& Sanguinetti 1989, Cardinal Mc-Teague \& Guillespie 2016), which were currently included into the new circumscription of Tragia s.l. (Romero e Sanguinetti 1989; Cardinal Mc-Teague e Guillespie 2016).

Among the species encountered in the study area, six had never been previously illustrated (Bernardia celastrinea, B. gambosa, B. scabra, B. sidoides, $B$. tamanduana, and Tragia cearensis) here for the first time.

\section{Key to the genera Bernardia and Tragia}

1. Erect plants; branches covered with simple trichomes; inflorescences unisexual; staminate flowers with 5-12 stamens; seeds cordiform or ellipsoid, carinate, testa crustaceous, smooth ................. 1. Bernardia 1'. Climbing plants; branches covered with urticating trichomes, sometimes simple, tector and capitate glandular; inflorescences bisexual; staminate flowers with 2-3 stamens; seeds spherical, not carinate, testa verrucose, papillose or smooth ......................................... 2. Tragia 


\section{Taxonomic Treatment}

1. Bernardia Houst. ex Mill., Gard. Dict. Abr. (ed. 4) vol. 1. 1754.

Herbs to shrubs, erect, monoecious or dioecious; branches cylindrical or slightly canaliculate, ramified; indumentum composed of simple trichomes present on vegetative and/or reproductive structures. Leaves alternate or verticillate, petiolate to subsessile, stipulate, simple, entire, the margin crenate or serrate, venation semicraspedodromous; basilaminar glands frequently present, paired or not. Inflorescence unisexual, staminate flowers in pseudoracemes and pistillate flowers in spike or umbelliform; bracts persistent; staminate flowers pedicellate, apetalous; sepals 3, valvate, stamens 5-12, anthers broadly elliptic, basifixed; pistillate flowers sessile on the bract, apetalous, sepals 5, imbricate, entire, ovary 3-carpelar, locules 1-ovulate, styles 3, bifid. Fruits capsules 3-lobed, subglobose, slightly to densely pilose, not corniculate, dehiscent or indehiscent; carpophore not persistent. Seeds cordiform or ellipsoid, ecarunculate, carinate, testa crustaceous, variegated or not, smooth.

\section{Key to the species of Bernardia occurring in Northeastern Brazil}

1. Plants herbaceous; leaves verticillate; basilaminar glands absent on the leaves 1.7 B. sidoides

1 '. Plants shrubby; leaves alternate; basilaminar glands present on the leaves

2. Leaves obovate with margin serrate only on the distal half; basilaminar glands paired

3. Stipules lanceolate; leaf blade $2-3.5 \mathrm{~cm}$ long; basilaminar glands prominent; staminate inflorescences $0.7-1 \mathrm{~cm}$ long

1.4 B. hamadryadica

3'. Stipules deltate; leaf blade $5.8-12.8 \mathrm{~cm}$ long; basilaminar glands not prominent; staminate inflorescences $2-4 \mathrm{~cm}$ long

1.5 B. pulchella

2 '. Leave elliptic, with margin completely serrate; basilaminar glands unpaired

4. Branches incanous

5. Stipules lanceolate, incanous; leaf blade incanous; ovary and styles velutinous; seeds ellipsoid, variegate, brown with black splotches ....................................... 1.6 B. scabra 5 ' Stipules deltate, strigose; leaf blade glabrescent; ovary pilose; styles glabrescent; seeds cordiform, not variegate, black ........

1.8 B. tamanduana

4'. Branches strigose, velutinous or pubescent on the youngest branches and pilose on the oldest

6. Stipules lanceolate or lanceolate to narrow-triangular; leaves pubescent or with abaxial surface pubescent and adaxial surface pilose only on the central vein and margins; stamens 5-8; capsule 3.5-8 mm diam.; seeds light brown or dark brown with black splotches

7. Branches pubescent on the youngest portion and pilose on the oldest; stipules lanceolate; leaf blade with apex cuneate, abaxial surface pubescent and adaxial surface pilose only on the central vein and margins; ovary incanous; styles glabrescent; capsule 5-8 mm diam., incanous; seeds cordiform, variegated, dark brown with black splotches .... 1.1 B. axillaris
7'. Branches velutinous; stipules lanceolate to narrowtriangular; leaf blade with apex attenuate, pubescent with trichomes distributed principally along the veins; ovary velutinous; styles pilose; capsule $3.5-5 \mathrm{~mm}$ diam., velutinous; seeds ellipsoid, not variegated, light brown .. 1.2 B. celastrinea 6'. Stipules deltate; leaves glabrescent; stamens 10-12; capsule 13-14 mm diam.; seeds black without splotches .. 1.3 B. gambosa

\subsection{Bernardia axillaris (Spreng.) Müll. Arg., Linnaea 34: 174. 1865.} Figure 1A-H

Shrubs ca. $2 \mathrm{~m}$ tall, dioecious; branches pubescent on the youngest branches and pilose on the oldest. Stipules 1.8-2 mm long, lanceolate, pubescent. Leaves alternate; petiole 1-2.5 mm long, pubescent; blade $4.5-6 \times 1.2-2 \mathrm{~cm}$, elliptic, base cuneate, apex cuneate, margin completely serrate, abaxial surface pubescent, adaxial surface pilose only on the central vein and margins, basilaminar glands $3-4$, not prominent, unpaired. Staminate inflorescence axillary, 2-3 $\mathrm{mm}$ long; bracts $0.8-1 \mathrm{~mm}$ long, broadly elliptic to ovate, pilose. Pedicel $1-1.2 \mathrm{~mm}$ long; sepals $0.8-1 \mathrm{~mm}$ long, lanceolate, pilose; stamens 5-6, filaments $0.2-0.3 \mathrm{~mm}$ long. Pistillate inflorescence axillary, spicate, $0.7-10 \mathrm{~mm}$ long; bracts $1-1.3 \mathrm{~mm}$ long, elliptic to ovate, incanous. Sepals $1-1.2$ $\mathrm{mm}$ long, elliptic to ovate, incanous; ovary globose, incanous; styles glabrescent. Capsule 5-8 mm diam., incanous. Seeds 4-5 mm long, cordiform, variegated, dark brown with black splotches.

Material selected: BRAZIL, BAHIA: Cruz das Almas, 12 67'00" S and 39 10 '18" W, 27.V.2012, fl., A.F.P. Machado 1136 (HUEFS). PARAÍBA: Matureia, $07^{\circ} 18^{\prime} 61^{\prime \prime} \mathrm{S}$ and $37^{\circ} 43^{\prime} 13^{\prime \prime} \mathrm{W}, 12$.VII.1997, fl., M.F. Agra 4044 (MO).

Bernardia axillaris is considered endemic to Brazil, known from the states of Bahia, Espírito Santo, and Rio de Janeiro, in the Atlantic Forest domain (Carrión 2018). The species is recorded here for the first time for Paraíba State, where it occurs in caatinga vegetation. In the study area, it was found principally in the Atlantic Forest on clayey soils, between 146 and 1,010 m elevation, flowering and fruiting all year.

It is very similar to $B$. scabra by its leave elliptic, with margin completely serrate. However, these species can be distinguished by the number of leaf glands (3-4 glands in B. axillaris vs. 9-12 in B. scabra). Additionally, the styles of $B$. axillaris are glabrescent while those of $B$. scabra are velutinous. The number of stamens can also distinguish these taxa (5-6 stamens in B. axillaris vs. 7-8 in B. scabra).

1.2 Bernardia celastrinea (Baill.) Müll. Arg., Prodr. 15(2): 921.1866. Figure 1I-N

Shrubs ca. $1 \mathrm{~m}$ tall, dioecious; branches velutinous. Stipules $2.5-3 \mathrm{~mm}$ long, lanceolate to narrow-triangular, velutinous. Leaves alternate; petiole 1.5-3 mm long, velutinous; blade $6.5-8.5 \times 1.8-2.5 \mathrm{~cm}$, elliptic, base cuneate, apex attenuate, margin completely serrate, pubescent, with trichomes distributed principally along the veins, basilaminar glands $3-5$, not prominent, unpaired. Staminate inflorescence axillary, in short pseudoracemes, 6-9 mm long; bracts 2-2.5 mm long, broadly elliptic to ovate, pubescent. Pedicel $0.8-1 \mathrm{~mm}$ long; sepals $0.7-0.8 \mathrm{~mm}$ long, lanceolate to ovate, pubescent; stamens 6-8, filaments $0.1-0.2$ $\mathrm{mm}$ long. Pistillate inflorescences axillary, spicate, $0.6-0.8 \mathrm{~mm}$ long; bracts 1.8-2 mm long, lanceolate to ovate, pubescent. Sepals 1.8-2 $\mathrm{mm}$ long, ovate, pubescent; ovary globose, velutinous; styles pilose. 


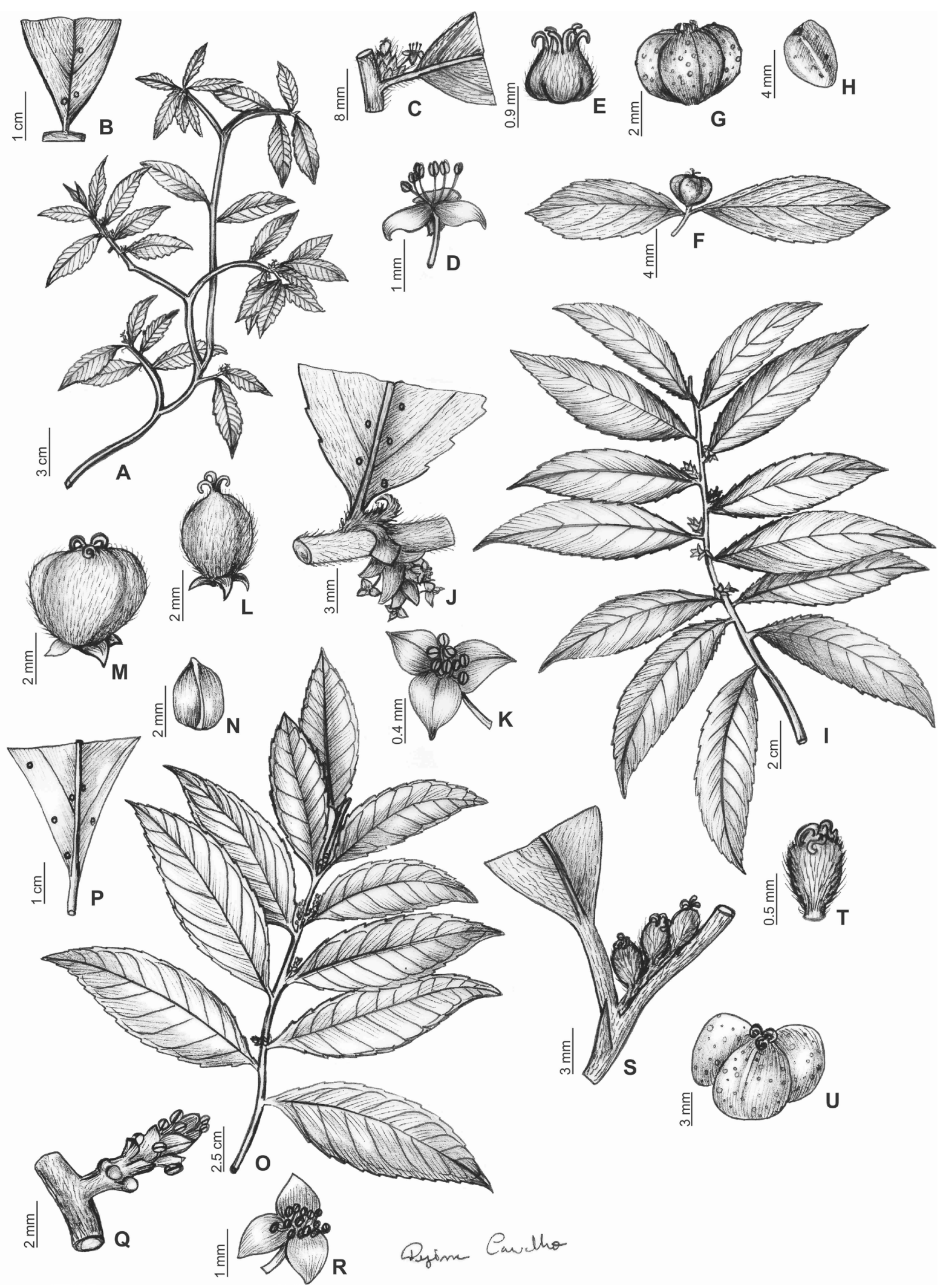

Figure 1. A-H: Bernardia axillaris. A: Branch. B: Base of the blade showing basilaminar glands. C: Staminate inflorescence. D: Staminate flower. E: Pistillate flower. F: Branch with fruit. G: Fruit. H: Seed. A-E (A.F.P. Machado 1136) and F-G (S.S. Simões 151). I-N: B. celastrinea (T.S. Santos 1252). I: Habit. J: Staminate inflorescence and basilaminar glands not paired. K: Staminate flower. L: Pistillate flower. M: Fruit. N: Seed. O-U: B. gambosa. O: Branch. P: Base of the blade showing basilaminar glands. Q: Staminate inflorescence. R: Staminate flower. S: Pistillate inflorescence. T: Pistillate flower. U: Fruit. O-T (L.M.N. Meyer et al. 8) and U (P. Fiaschi et al. 1698). 
Capsule 3.5-5 mm diam., velutinous. Seeds $2-3 \mathrm{~mm}$ long, ellipsoid, not variegated, light brown.

Material examined: BRAZIL, BAHIA: Ipiaú, 14 ${ }^{\circ} 13^{\prime} 72^{\prime}$ S and 39³'39” W, 31.X.1970, fl. and fr., T.S. Santos 1252 (CEPEC).

Additional Material: BRAZIL, RIO DE JANEIRO: Rio de Janeiro, $22^{\circ} 54^{\prime} 12^{\prime \prime} \mathrm{S}$ and 43'12'27" W, 18.IX.1946, fl., P. Occhioni 698 (RB).

The species is endemic to Brazil, occurring in ombrophilous Atlantic Forest vegetation in the states of Rio de Janeiro and São Paulo (Carrión 2018). It is recorded here for the first time in Northeastern Brazil, in Bahia State, were it grows in Atlantic Forest on clayey soils at $153 \mathrm{~m}$ elevation. Flowering and fruiting most of the year.

Bernardia celastrinea can be recognized by having staminate inflorescences in pseudoracemes, fruits up to $5 \mathrm{~mm}$ diam., and seeds light brown. Among the species found in Northeastern Brazil was possible to observe monoecious individuals of $B$. celastrinea and $B$. pulchella, but $B$. celastrinea has elliptic leaves, the margin completely serrate, and 3-5 unpaired glands, contrasting with B. pulchella which has leaves obovate, the margin serrate only on the distal half, and only two paired glands.

\subsection{Bernardia gambosa Müll. Arg., Fl. Bras. 11 (2): 391. 1874.}

Figure 1O-U

Shrubs ca. $2 \mathrm{~m}$ tall, dioecious; branches strigose. Stipules $1-2.5 \mathrm{~mm}$ long, deltate, strigose. Leaves alternate; petiole 0.5-12 $\mathrm{mm}$ long, strigose; blade 12-22.5 $\times 5.5-11 \mathrm{~cm}$, elliptic, base cuneate, apex cuneate, margin completely serrate, glabrescent, basilaminar glands $6-12$, not prominent, unpaired. Staminate inflorescence axillary, $1.5-2.5 \mathrm{~cm}$ long; bracts $0.5-1 \mathrm{~mm}$ long, broadly elliptic to ovate, strigose. Pedicel 1.5-2 mm long; sepals 1-1.5 mm long, ovate, pubescent; stamens 10-12, filaments $0.2-0.3 \mathrm{~mm}$ long. Pistillate inflorescence terminal, spicate, 0.7-13 mm long; bracts 1.5-2 mm long, ovate, strigose. Sepals 1-1.2 $\mathrm{mm}$ long, ovate, strigose; ovary subglobose, strigose; styles strigose. Capsule 13-14 mm diam., strigose. Seeds 5-7 mm long, cordiform, not variegated, black.

Material examined: BRAZIL, BAHIA: Buerarema, $15^{\circ} 5^{\prime} \mathrm{S}$ and $39^{\circ} 19^{\prime}$ W, 15.X.2003, fr., P. Fiaschi et al. 1698 (CEPEC).

According to Carrión (2018), B. gambosa is endemic to Brazil and its occurrence has been confirmed for Bahia State, with a possible occurrence in Rio de Janeiro (Southeast region). The species is found in Atlantic Forest vegetation in areas of semi-deciduous seasonal and ombrophilous forests. In the study area, it has also been observed in areas of caatinga and areas of restinga vegetation on clayey soils at altitudes between 22 and $400 \mathrm{~m}$ elevation. Flowers and fruits were encountered most of the year.

Among the species in the study area, it has the largest leaves $(12-22.5 \times 5.5-11 \mathrm{~cm} v s .2-12.5 \times 0.5-3.5 \mathrm{~cm}$ in the other species), and the largest number of stamens, 10-12 (vs. up to nine in the other species). It is similar to $B$. tamanduana by having elliptic leaves with up to 12 unpaired basilaminar glands, but differing by the length of its leaves, number of stamens, and indumentum on the style. Bernardia tamanduana has leaves up to $14.2 \mathrm{~cm}$ long, only 6 to 8 stamens, and styles glabrescent ( $v s$. leaves up to $22.5 \mathrm{~cm}$ long, 10 to 12 stamens, and styles strigose in B. gambosa).
1.4 Bernardia hamadryadica J.F. Carrión \& Cordeiro, Phytotaxa 317 (1): 69-75. 2017

Shrubs ca. $1.7 \mathrm{~m}$ tall, dioecious; branches slightly canaliculate, pilose. Stipules 3-4 mm long, lanceolate, pilose. Leaves alternate; petiole 2-3 $\mathrm{mm}$ long, hirsute; blade 2-3.5 $\times 0.5-1.5 \mathrm{~cm}$, obovate, base cuneate, apex cuneate, margin serrate only on the distal half, abaxial surface hirsute, adaxial surface pilose, basilaminar glands $3-5$, prominent, unpaired. Staminate inflorescences axillary, $0.7-1 \mathrm{~cm}$ long; bracts $1.2-1.3 \mathrm{~mm}$ long, ovate, pubescent. Pedicel 2-4 mm long; sepals 1-1.2 mm long, lanceolate, pubescent; stamens $6-8$, filaments $0.6-0.8 \mathrm{~mm}$ long. Pistillate inflorescences axillary, spicate, 5-6 mm; bracts $2-2.5 \mathrm{~mm}$ long, ovate, pubescent. Sepals 1-1.2 mm long, ovate, pubescent; ovary globose, velutinous; styles pilose. Capsule 7-10 mm diam., velutinous. Seeds 3.2-4 mm long, cordiform, not variegated, light brown.

Material examined: BRAZIL, BAHIA: Rio de Contas, 1349'34" S and 41 ${ }^{\circ} 35^{\prime}$ '"' W, 5.XII.2004, fl., R.M. Harley 55283 (HUEFS).

This species is endemic to Bahia State (Carrión 2018), where it occurs in caatinga, carrasco, and deciduous forests (Carrión et al. 2017). It grows on soils with limestone, quartzite, and metamorphic sandstone rock outcrops in the study area, at elevations varying between 534 and $970 \mathrm{~m}$ elevation. Flowers and fruits were found in April and December.

It is morphologically similar to $B$. pulchella by the shape and margin of the leaves. However, B. hamadryadica has leaves up to $3.5 \mathrm{~cm}$ long and with three to five prominent basilaminar glands ( $v s$. leaves up to $12.8 \mathrm{~cm}$ long and with two non-prominent basilaminar glands).

Illustration: Carrión et al. (2017)

1.5 Bernardia pulchella (Baill.) Müll. Arg., Fl. Bras. 11 (2): 392.1874. Figure 2A-F

Shrubs ca. $2 \mathrm{~m}$ tall, dioecious; branches strigose. Stipules 2-3 mm long, deltate, strigose. Leaves alternate; petiole $0.3-5 \mathrm{~mm}$ long, strigose; blade $5.8-12.8 \times 1.6-3.3 \mathrm{~cm}$, obovate, base acute, apex acute, margin serrate only on the distal half, pubescent, basilaminar glands 2 , not prominent, paired. Staminate inflorescences axillary, 2-4 cm long; bracts $0.7-1$ $\mathrm{mm}$ long, ovate, strigose. Pedicel $0.8-1.2 \mathrm{~mm}$ long; sepals $0.8-1 \mathrm{~mm}$ long, ovate, pilose; stamens $6-8$, filaments $0.1-0.2 \mathrm{~mm}$ long. Pistillate inflorescences terminal, spicate, $1-1.6 \mathrm{~cm}$ long; bracts $2.5-3 \mathrm{~mm}$ long, ovate, pilose. Sepals 1-1.2 mm long, ovate, pubescent along the margin; ovary globose, velutinous; styles connate half their length, pilose. Capsule 3-5 mm diam., velutinous. Seeds $1.8-3 \mathrm{~mm}$ long, cordiform, not variegated, dark brown.

Material selected: BRAZIL, BAHIA: Cruz das Almas, 1240'13" S and 3906'06" W, XII.1950, fr., G. Pinto 641 (RB).

This species occurs in Bolivia and in Brazil (Jorgensen et al. 2014), where it has been cited for the states of Mato Grosso, Mato Grosso do Sul, Minas Gerais, Paraná, Rio Grande do Sul, Santa Catarina, and São Paulo, being common in the Atlantic Forest in areas of gallery forest, ombrophilous forest, and mixed ombrophilous forest, and in anthropogenically altered environments (Carrión 2018). Bernardia pulchella is cited here for the first time for Northeastern Brazil, where to date it is has been found in Bahia State. It grows in Atlantic Forest vegetation on clayey soils, at elevations between 108 and 220 meters elevation. Flowers were observed in November and fruits in December. 


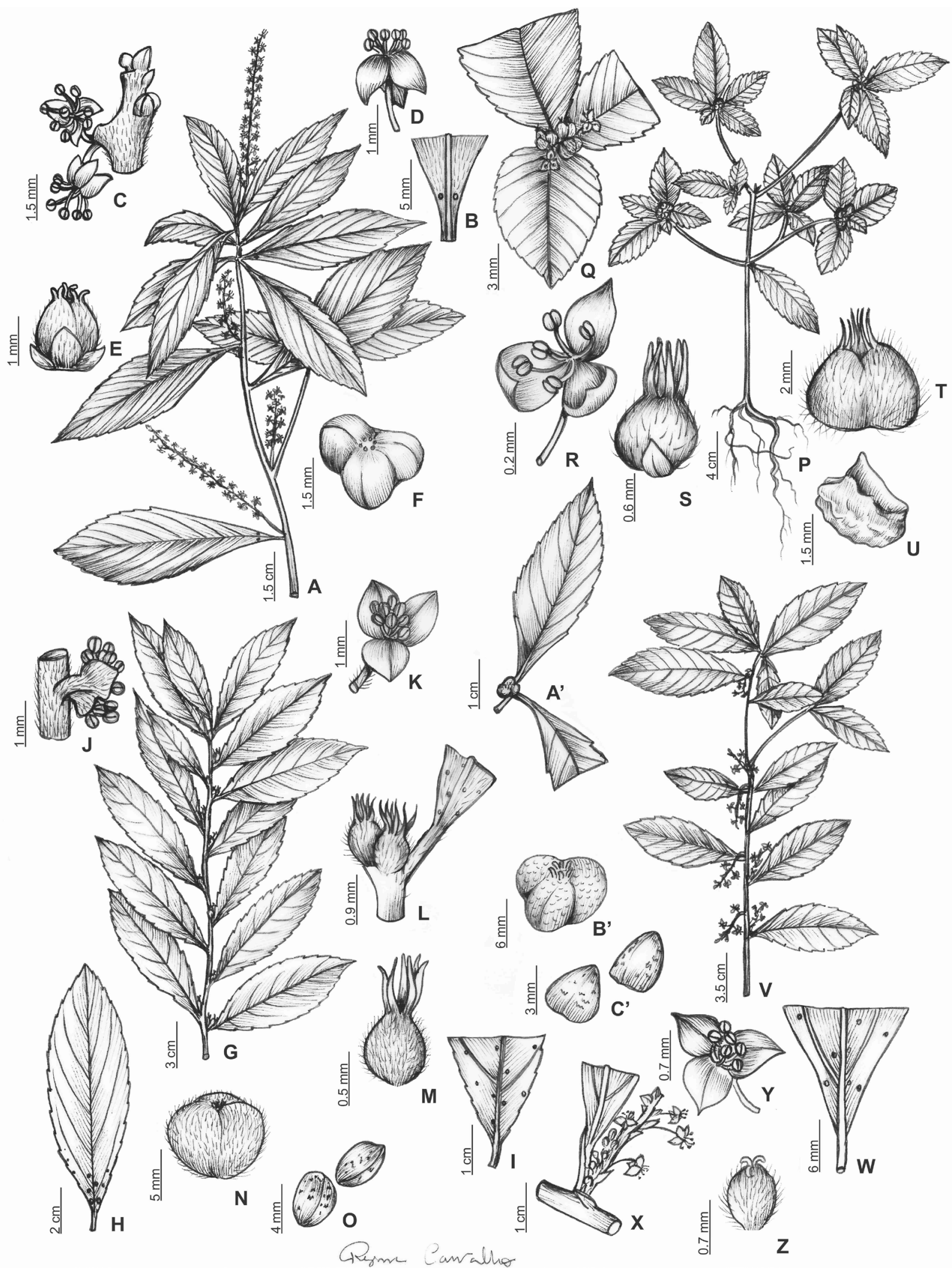

Figure 2. A-F: Bernardia pulchella (J. Bueno 14). A: Branch. B: Base of the blade, showing basilaminar glands. C: Staminate inflorescence. D: Staminate flower. E: Pistillate flower. F: Fruit. G-O: B. scabra (A.M. Carvalho \& J. Catti 742). G: Branch. H: Leaf. I: Base of the blade showing basilaminar glands. J: Staminate inflorescence. K: Staminate flower. L: Pistillate inflorescence. M: Pistillate flower. N: Fruit. O: Seed. P-U: B. sidoides (R.A. Silva 657). P: Habit. Q: Staminate and pistillate inflorescences. R: Staminate flower. S: Pistillate flower. T: Fruit. U: Seed. V-C': B. tamanduana. V: Branch. W: Base of the blade showing basilaminar glands. X: Staminate inflorescence. Y: Staminate flower. Z: Pistillate flower. A': Branch with fruit. B': Fruit. C': Seeds. V-Z' (A.G. Silva et al. 218) and A'-C' (D. Cardoso 1215). 
Bernardia pulchella is morphologically similar to B. hamadryadica by its obovoid leaves that are serrate only along the distal half, and paired glands. The distinctions between those two species were discussed in the commentaries concerning $B$. hamadryadica.

1.6 Bernardia scabra Müll. Arg., Fl. Bras. 11 (2): 396. 1874.

Figure 2G-O

Shrubs ca. $2.5 \mathrm{~m}$ tall, dioecious; branches incanous. Stipules 2-2.8 $\mathrm{mm}$ long, lanceolate, incanous. Leaves alternate; petiole $3-5 \mathrm{~mm}$ long, pubescent; blade 7-12.5 $\times 3-3.5 \mathrm{~cm}$, elliptic, base cuneate, apex attenuate, margin completely serrate, incanous, basilaminar glands 9-12, not prominent, unpaired. Staminate inflorescences axillary, 4-6 $\mathrm{mm}$ long; bracts $1-1.2 \mathrm{~mm}$ long, broadly elliptic, pubescent. Pedicel 1-1.2 mm long; sepals $0.9-1 \mathrm{~mm}$ long, lanceolate to ovate, pubescent; stamens 7-8, filaments $0.2-0.3 \mathrm{~mm}$ long. Pistillate inflorescences axillary, spicate, $0.4-12 \mathrm{~mm}$ long; bracts $1-1.2 \mathrm{~mm}$ long, lanceolate to ovate, pubescent. Sepals $0.9-1 \mathrm{~mm}$ long, lanceolate to ovate, pubescent; ovary globose, velutinous; styles connate at base, velutinous. Capsule 5-10 mm diam., velutinous. Seeds 4-6 mm long, ellipsoid, variegated, brown with black splotches.

Material selected: BRAZIL, BAHIA: Arataca, 15 $10^{\circ} 42^{\prime \prime} \mathrm{S}$ and 39²0'9” W, 12.X.2008, fl., A.B. Jardim et al. 119 (RB).

According to Carrión (2018), B. scabra is known only from Northeastern Brazil, in Bahia State, with possible occurrence in Rio de Janeiro in Southeastern Brazil; it is common in areas of semi-deciduous seasonal and ombrophilous forests. It was also encountered in gallery forests, restinga, and humid forest sites on clayey soils, at elevations between 40 and $860 \mathrm{~m}$ elevation. Flowers were observed in October and fruits in December.

Bernardia scabra is characterized by leaves with apex attenuate, 9 to 12 unpaired basilaminar glands, and styles velutinous. Pistillate inflorescences axillary, spicate, leaves elliptic and glands not paired make it morphologically similar to $B$. axillaris. The distinctions between those two species are discussed under B. axillaris.

1.7 Bernardia sidoides (Klotzsch) Müll. Arg., Linnaea 34: 177. 1865. Figure 2P-U

Herbs ca. $50 \mathrm{~cm}$ tall, erect, monoecious; branches pubescent. Stipules $0.8-1 \mathrm{~mm}$ long, narrow elliptic to lanceolate, pilose. Leaves verticillate; petiole $0.5-1 \mathrm{~cm}$ long, pubescent; blade $4.5-6.7 \times 2.4-2.6 \mathrm{~cm}$, elliptic, base cuneate, apex cuneate, margin completely serrate, abaxial surface pilose on the veins, adaxial surface pilose, basilaminar glands absent. Staminate inflorescences terminal, 3-4 mm long; bracts broadly elliptic, pilose. Pedicel $0.5-1 \mathrm{~mm}$ long; sepals $0.2-0.3 \mathrm{~mm}$ long, lanceolate to ovate, glabrescent; stamens 5, filaments $0.1-0.2 \mathrm{~mm}$ long. Pistillate inflorescences terminal, spicate, $5-7 \mathrm{~mm}$ long; bracts $1-1.5 \mathrm{~mm}$ long, lanceolate to ovate, pilose. Sepals $0.8-1 \mathrm{~mm}$ long, lanceolate, pilose; ovary subglobose, pilose; styles hirsute. Capsule 4-6 mm diam., hirsute. Seeds 2.5-3 mm long, ellipsoid, not variegated, dark brown.

Material selected: BRAZIL, ALAGOAS: Piranhas, 962'36" $\mathrm{S}$ and 37'75'66" W, 27.VII.1999, fl. and fr., R.A. Silva 657 (PEUFR). BAHIA: Milagres, $12^{\circ} 87^{\prime} 13^{\prime \prime} \mathrm{S}$ and $39^{\circ} 85^{\prime} 25^{\prime \prime} \mathrm{W}, 13 . \mathrm{III} .2005$, fl. and. fr., F. França 5173 (HUEFS). PARAÍBA: São José of Piranhas,
7'07'15" S and 38'30'07' W, 19.VII.2008, fl., J.R. Andrade et al. 96 (PEUFR). PERNAMBUCO: Serra Talhada, $7^{\circ} 59^{\prime} 31^{\prime \prime} \mathrm{S}$ and $38^{\circ} 17^{\prime} 53^{\prime \prime}$ W, 3.V.2017, fl. and fr., M.O. Santos et al. 45 (HUNEB). PIAUÍ: Cocal, $3^{\circ} 40^{\prime} 83$ " S and 41 ${ }^{\circ} 43$ '58" W, 23.II.2003, fl. and fr., E.M.F. Chaves 163 (HUEFS). RIO GRANDE DO NORTE: Serra Negra do Norte, 658'33" S and $37^{\circ} 23$ '33" W, 20.V.2005, fl. and fr., R.T. Queiroz 375 (HUEFS). SERGIPE: Canindé do São Francisco, 9³3'23" S and 37 56'28” W, 28.III.2000, fl. and fr., R.A. Silva \& D. Moura 1431 (PEUFR).

Bernardia sidoides occurs in Brazil, Costa Rica, Guatemala, Guyana, Mexico, Nicaragua, and Venezuela (Cervantes 2006). In Brazil, it has been recorded in the states of Alagoas, Bahia, Ceará, Paraíba, Pernambuco, Piauí, Rio Grande do Norte, and Sergipe in caatinga vegetation, seasonal deciduous forests, and also on rock outcrops (Carrión 2018). Flowers and fruits were recorded throughout the year.

This is the only species in the study area with verticillate leaves. It is also the only herbaceous monoecious plant with staminate and pistillate inflorescences in terminal.

1.8 Bernardia tamanduana (Baill.) Müll. Arg., Prodr. 15 (2): 920.1866. Figure 2V-C'

Shrubs ca. $4 \mathrm{~m}$ tall, dioecious; branches incanous. Stipules $2.8-3.1 \mathrm{~mm}$ long, deltate, strigose. Leaves alternate, subsessile; petiole 3-5 mm long, strigose; blade 9-14.2 ×3.2-5 cm, elliptic, base cuneate, apex cuneate, margin completely serrate, glabrescent, basilaminar glands $9-12$, not prominent, unpaired. Staminate inflorescences axillary, $1-3 \mathrm{~cm}$ long; bracts $0.8-1.2 \mathrm{~mm}$ long, deltate to ovate, glabrescent. Pedicel 1-1.2 $\mathrm{mm}$ long; sepals $0.7-0.8 \mathrm{~mm}$ long, lanceolate, pilose; stamens $6-8$, filaments $0.1-0.2 \mathrm{~mm}$ long. Pistillate inflorescences terminal, spicate, 3-9 mm long; bracts 1-1.2 mm long, ovate, pilose. Sepals $0.8-1 \mathrm{~mm}$ long, lanceolate, pilose; ovary globose, pilose; styles connate half their length, glabrescent. Capsule 8-10 mm diam., velutinous. Seeds 3-5 mm long, cordiform, not variegated, black.

Material selected: BRAZIL, ALAGOAS: Santana do Riacho, 19'17'60" S and 43'00'00" W, 20.XII.1974, fl., A.D. Andrade-Lima 7780 (HUEFS). BAHIA: Almadina, 14 $4^{\circ} 70^{\prime} 53^{\prime \prime} \mathrm{S}$ and $39^{\circ} 63^{\prime} 72^{\prime \prime} \mathrm{W}$, 3.VIII.1971, fl., R.S. Pinheiro 1537 (CEPEC). CEARÁ: Guaramiranga, 4'26'33" S and 38'93'31" W, 7.I.1994, fl., M.R. Oliveira $s / n$ (UFP 52285). PARAÍBA: Santana do Riacho, $7^{\circ} 13$ ' $60^{\prime \prime} \mathrm{S}$ and $37^{\circ} 20^{\prime} 59^{\prime \prime}$ W, 16.IV.1993, fl., M.F. Agra 1964 (IPA). PERNAMBUCO: Brejo da Madre de Deus, 8¹1'14" S and 36 24'63" W, 19.I.2000, fl., A. G. Silva et al 218 (CEPEC).

This species is endemic to Brazil (Forzza 2010), in the states of Alagoas, Bahia, Ceará, Minas Gerais, Paraíba, and Pernambuco, where it grows in caatinga, atlantic forest, carrasco, deciduous seasonal forest, and semi-deciduous seasonal forest (Carrión 2018). It has also been observed in Northeastern Brazil in gallery forests, and montane ombrophilous forests on clayey and rocky soils at elevations between 234 and 1,010 m elevation. Flowers and fruits were encountered during the entire year.

Bernardia tamanduana is characterized as a dioecious shrub, ca. 4 $\mathrm{m}$ tall, with its inflorescences terminal, spicate. It is morphologically similar to B. gambosa; the two species are compared under the latter. 
2. Tragia L., Sp. Pl. 2: 980. 1753.

Climbing herbs, monoecious; branches cylindrical or slightly canaliculate, ramified; indumentum composed of urticating trichomes, tector, simple, and capitate glands. Leaves alternate, simple, entire, the margin serrate, petiolate, stipulate, venation craspedodromous; basilaminar glands absent. Inflorescences bisexual, terminal or axillary, racemose, staminate flowers in distal nodes, solitary, pistillate flowers in proximal nodes, solitary; bracteoles persistent; staminate flowers pedicellate, apetalous, sepals 3 , valvate, stamens $2-3$, anthers broadly elliptic, basifixed; pistillate flowers pedicellate, apetalous, sepals 6 , imbricate, entire, ovary 3-carpelar, generally hispid, urticating, locules 1-ovulate, styles 3, free or united, stigma smooth or papillose. Fruit a capsule 3-lobed, subglobose, pubescent or hirsute, sometimes corniculate, septicidal-loculicidal, carpophore persistent. Seeds spherical, ecarunculate, not carinate, testa variegated or not, verrucose, smooth or tuberculate, sometimes papillose.

\section{Key to the species of Tragia in Northeastern Brazil}

\section{Plants lacking capitate glandular trichomes}

2. Stipules narrowly triangular; styles pilose; seeds black, testa verrucose 2.2 T. cearensis

2'. Stipules lanceolate; styles glabrescent; seeds light brown, testa papillose 2.5 T. volubilis

1'. Plants with capitate glandular trichomes on both vegetative and reproductive parts

3. Branches pubescent; leaf with attenuate apex; staminate bracts elliptic; styles glabrescent; seeds with papillose testa .. 2.1 T. bahiensis 3'. Branches hirsute or velutinous; leaf with acute apex; staminate bracts lanceolate; styles pubescent or pilose; seeds with smooth or tuberculate testa

4. Styles pilose; capsule hirsute; seeds with smooth testa, variegated, black with brown splotches ........ 2.3 T. chlorocaulon 4'. Styles pubescent; capsule pubescent; seeds with tuberculate testa, not variegated, dark brown, without brown splotches ........ 2.4 T. friesii

2.1 Tragia bahiensis Müll. Arg., Linnaea 34: 182. 1865.

\section{Figure $3 \mathrm{~A}-\mathrm{G}$}

Climbing herbs; branches cylindrical, pubescent; trichomes simple, urticating trichomes and capitate glands on the vegetative and reproductive parts. Stipules 1.6-1.8 $\mathrm{mm}$ long, lanceolate, pubescent. Petiole 1.5-3 cm long, pubescent; blade 3-9.3 × 1.7-3.9 cm long, lanceolate to ovate, base subcordate to cordate, apex attenuate, abaxial surface pubescent, adaxial surface pilose. Inflorescence axillary, racemose, $1-3.2 \mathrm{~cm}$ long; bracts $0.8-1 \mathrm{~mm}$ long, elliptic, pilose. In staminate flowers the pedicel $0.6-0.8 \mathrm{~mm}$ long; bracteoles $0.8-1 \mathrm{~mm}$ long, elliptic, pubescent; sepals $0.7-0.8 \mathrm{~mm}$ long, lanceolate, pubescent; stamens 3 , filaments $0.1-0.2 \mathrm{~mm}$ long. In pistillate flowers the pedicel 1.8-2 mm long; bracteoles $0.8-1 \mathrm{~mm}$ long, lanceolate, pubescent; sepals 0.8-0.9 mm long, lanceolate, pubescent; ovary globose, pubescent; styles connate for half their length, glabrescent. Capsule 2-4 mm diam., pedicel 1.8-2 mm long, subglobose, pubescent. Seeds 1-1.2 mm diam., testa papillose, not variegated, dark brown.
Material selected: BRAZIL, BAHIA: Barreiras, 28.XII.1954, fl. and fr., Black 54-17894 (IAN).

Additional Material: BRAZIL, GOIÁS: Ponte Alta, $14^{\circ} 23,5^{\prime} \mathrm{S}$ and 48 25,3' W, 5.II.2005, fl. and fr., Reeves et al. 3035 (CEN). MINAS GERAIS: Monte Azul, 15'12'36" S and 42 53'49' W, 22.IV.2006, fr., Carneiro-Torres et al. 715 (HUEFS).

This species occurs in Argentina, Bolivia, Brazil, and Paraguay (Múlgura 1991). In Brazil, it is known from the states of Bahia, Mato Grosso, Minas Gerais, Paraná, Rio Grande do Sul, and São Paulo, in the Caatinga and Cerrado domains and in areas of campo limpo (Flora do Brasil 2020 under construction). It grows in arboreal-shrub caatinga vegetation on sandy and rocky soils and on gray limestone outcrops between 60-1,000 m elevation. Individuals with flowers and fruits were collected from April to August.

Tragia bahiensis is characterized principally by having leaves with subcordate to cordate bases, apex attenuate, and fruit with pedicel up to $2 \mathrm{~mm}$ long. Additionally, it has simple urticating trichomes and capitate glands on the reproductive and vegetative structures of the plant, like Tragia friesii. However, these species can be distinguished by staminate bracts elliptic ( $v s$. staminate bracts lanceolate in T. friesii), styles glabrescent ( $v s$. styles pubescent), and seeds with papillose testa (vs. seeds with tuberculate testa).

\subsection{Tragia cearensis Pax \& K. Hoffm., Pflanzenr. IV. 147. XVII (Heft} 85): 186.1924.

Figure $3 \mathrm{H}-\mathrm{K}$

Climbing herbs; branches cylindrical, slightly canaliculate, hirsute; with simple and urticating trichomes on the vegetative and reproductive parts; glandular trichomes absent. Stipules $2-2.3 \mathrm{~mm}$ long, narrowly triangular, pilose. Petiole 1-3.6 cm long, hirsute; blade 6-8.5 × 3-4 cm, ovatetriangular, base cordate, apex attenuated, hirsute. Inflorescence axillary, racemose, $1.2-1.5 \mathrm{~cm}$ long; bracts $0.8-1 \mathrm{~mm}$ long, lanceolate, pilose. In staminate flowers the pedicel $1-1.3 \mathrm{~mm}$ long; bracteoles $0.8-1 \mathrm{~mm}$ long, lanceolate, pilose; sepals $0.9-1 \mathrm{~mm}$ long, lanceolate, pilose; stamens 3, filaments $0.1-0.2 \mathrm{~mm}$ long. In pistillate flowers the pedicel $1-1.2 \mathrm{~mm}$ long; bracteoles $0.8-1 \mathrm{~mm}$ long, lanceolate, pilose; sepals $0.9-1 \mathrm{~mm}$ long, lanceolate, pilose; ovary globose, hirsute; styles connate for half their length, pilose. Fruit 7-8 mm diam., pedicel 1-1.2 mm long, subglobose, hirsute. Seeds 2-2.3 mm diam., testa verrucose, not variegated, black.

Material examined: BRAZIL, ALAGOAS: São José da Tapera, 9'37'34"'S and 37'22'42'”,14.VII.2000, fr., R.P. Lyra-Lemos 4732 (MAC). CEARÁ: Santa Quitéria, 4'35' S and 39²4' W, 24.IV.2012, fl. and fr., J.P. Souza et al. 10889 (RB). PARAÍBA: Areia, 12.VI.1953, fl. and fr., J.C. Moraes 1155 (US). RIO GRANDE DO NORTE: Serra Negra do Norte, 6 56 ' 66" S and $37^{\circ} 25^{\prime}$ 'W, 14.IV.2006, fl. and fr., R.T. Queiroz 677 (HUEFS). SERGIPE: Canindé de São Francisco, 965'99” S and 3778'93" W, 8.IV.2011, fl. and fr., A.A.B. Silva \& M.P. Souza 20 (EAC).

Tragia cearensis is endemic to Brazil and was previously cited only for Ceará State in caatinga vegetation (Flora do Brasil 2020 under construction). It is recorded here for the first time from Alagoas, Paraíba, Rio Grande do Norte and Sergipe, where it grows in Atlantic Forest in canopy gaps and gallery forest vegetation on sandy and clayey soils, at elevations between 60 and 990 meters elevation. Individuals with flowers and fruits were collected from January to July. 


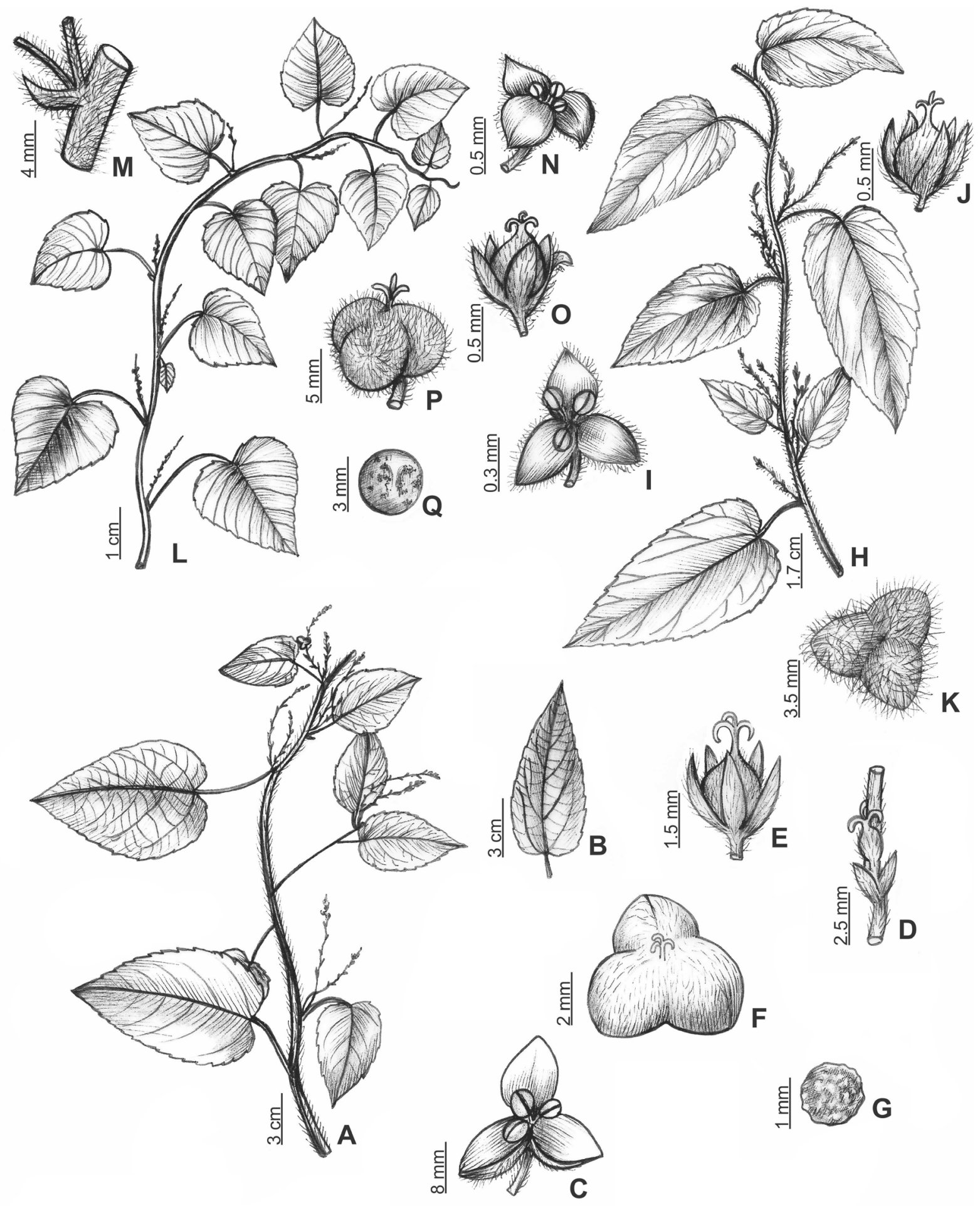

Regn- canrtwo

Figure 3. A-G: Tragia bahiensis (Black 54-17894). A: Branch. B: Leaf. C: Staminate flower. D: Branch with pistillate flower. E: Pistillate flower. F: Fruit. G: Seed. H-K: T. cearensis (R.T. Queiroz 677). H: Branch. I: Staminate flower. J: Pistillate flower. K: Fruit. L-Q: T. chlorocaulon (G. Eiten \& L.T. Eiten 4836). L: Branch. M: Detail of the stipule. N: Staminate flower. O: Pistillate flower. P: Fruit. Q: Seed. 
It is the only species in the present study that presents black verrucose seeds. Additionally, it does not have glandular trichomes, like in Tragia volubilis, but only simple and urticating trichomes covering its vegetative and reproductive structures. However, these species can be distinguished by the length of the fruit pedicel $(1-1.2 \mathrm{~mm}$ in $T$. cearencis vs $1.5-2 \mathrm{~cm}$ in $T$. volubilis).

\subsection{Tragia chlorocaulon Baill., Étude Euphorb. 461. 1858.} Figure 3L-Q

Climbing herbs; branches cylindrical, velutinous; with simple and urticating trichomes and capitate glands on the vegetative and reproductive parts. Stipules $4-5 \mathrm{~mm}$ long, narrow-triangular to lanceolate, pilose. Petiole 1-2.4 cm long, hirsute; blade 3.5-8.5 $\times$ $3.2-8.8 \mathrm{~cm}$, cordiform, base cordate, apex acute, hirsute. Inflorescence axillary, racemose, $4.5-11.5 \mathrm{~cm}$ long; bracts 1.9-2 $\mathrm{mm}$ long, lanceolate, pilose. In staminate flowers the pedicel $0.8-1 \mathrm{~mm}$; bracteoles $1-1.2 \mathrm{~mm}$ long, lanceolate, pilose; sepals 1-1.2 mm, lanceolate, pilose; stamens 3 , filaments $0.1-0.2 \mathrm{~mm}$ long. Pistillate flowers sessile; bracteoles 1.2-1.4 $\mathrm{mm}$ long, lanceolate, pilose; sepals $1-1.3 \mathrm{~mm}$ long, pubescent; ovary globose, hirsute; styles connate for half their length, pilose. Capsule 8-10 mm diam., sessile, subglobose, hirsute. Seeds 3-4 mm diam., testa smooth, variegated, black with brown splotches.

Material examined: BRAZIL, MARANHÃO: Loreto, 7²43'33” S and $45^{\circ} 00^{\prime}$ W, 6.VI.1962, fl. and fr., G. Eiten \& L.T. Eiten 4836 (SP). Additional Material: BRAZIL, MINAS GERAIS: Carangola, $20^{\circ} 43^{\prime} 59^{\prime}$ ' S and $42^{\circ} 01^{\prime} 46^{\prime \prime} \mathrm{W}, 10 . \mathrm{VII} .2009$, fl. and fr., F. Marcolino

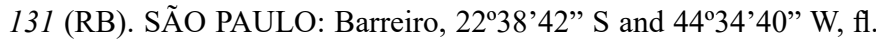
and fr., G.E.R.F. Edwall 68 (SP).

This species is recorded from Bolivia and Brazil (Jorgensen et al. 2014). According to Flora do Brasil 2020 (under construction), this species had been observed only in the Central-Western region of Brazil (Federal District and state of Goiás), where it grows in the Cerrado domain. The present study records the species from the states of Maranhão (a new occurrence for that species in Northeastern Brazil), Minas Gerais and São Paulo, growing in cerrado vegetation on clayey soils ca. 250 meters elevation.

Tragia chlorocaulon can be characterized by its cordiform leaves and simple and urticating trichomes and capitate glands on the vegetative and reproductive structures of the plant. The species stands out as being the only one in the study area to have seeds with the testa smooth and variegated, black with brown splotches ( $v s$. seeds with testa papillose, verrucose or tuberculate in the other species). It is similar to T. bahiensis by its simple and urticating trichomes and capitate glands. However, T. chlorocaulon has leaf blade cordiform and hirsute, and the inflorescences $4.5-11.5 \mathrm{~cm}$ long ( $v s$. lanceolate to ovate, with abaxial surface pubescent and adaxial surface pilose and inflorescences 1-3.2 cm long).

\subsection{Tragia friesii Pax \& K. Hoffm., Pflanzenr. IV. 147 XVII (Heft 85):} 186. 1924

Figure 4A-F

Climbing herbs; branches cylindrical, hirsute; trichomes simple, urticant and glandular on the vegetative and reproductive parts. Stipules 2.5-3 $\mathrm{mm}$ long, deltate, pilose. Petiole 1.5-2 cm long, hirsute; blade 4-8 $\times$ $4.5-5.7 \mathrm{~cm}$, ovate, base cordate, apex acute, pubescent. Inflorescences axillary, racemose, 6-9 cm long; bracts $1-1.2 \mathrm{~mm}$ long, lanceolate, pilose. In staminate flowers the pedicel 1-1.2 mm long; bracteoles $0.8-1 \mathrm{~mm}$ long, lanceolate, pilose; sepals $1.2-1.3 \mathrm{~mm}$ long, lanceolate, pilose; stamens 3 , filaments $0.1-0.2 \mathrm{~mm}$ long. Pistillate flowers sessile; bracteoles $0.9-1 \mathrm{~mm}$ long, narrowly elliptic, pubescent; sepals 0.8-1 mm long, lanceolate, pubescent; ovary globose, pubescent; styles connate at base, pubescent. Capsule 4-6.2 mm diam., sessile, subglobose, pubescent. Seeds 2.5-3 mm diam., testa tuberculate, not variegated, dark brown.

Material examined: BRAZIL, ALAGOAS: Piranhas, 9'62'36" $\mathrm{S}$ and 3775'66" W, 11.VIII.1999, fr., R.A. Silva 807 \& D. Moura (PEUFR). BAHIA: Milagres, 1209'16" S and 39 $82^{\prime}$ '58" W, 16.III.1997, fl. and fr., F. França et al. 2169 (ALCB). PARAÍBA: Queimadas, 7²2’36" and $35^{\circ} 56^{\prime} 41^{\prime \prime}, 18 . I V .2006$, fl. and fr., M.F. A. Lucena \& A. Araújo 1315 (UFP). PERNAMBUCO: Ipubi, $7^{\circ} 65^{\prime} 19^{\prime \prime} \mathrm{S}$ and $40^{\circ} 14^{\prime} 88^{\prime \prime} \mathrm{W}$, 15.IV.2010, fr., A.M. Miranda et al. 6166 (HST). SERGIPE: Porto da Folha, $10^{\circ} 02$ '21'" and 37'24'90", 14.VI.2006, fl. and fr., M.F. A. Lucena et al. 1833 (UFP).

Tragia friesii occurs in Bolivia and Brazil (Foster 1958, Múlgura \& Sanguinetti 1989). In Brazil, it was only known from Pernambuco State, in the Caatinga domain (Múlgura \& Sanguinetti 1989, Flora do Brasil 2020 under construction). It is recorded here for the first time in the states of the Alagoas, Bahia, Paraíba and Sergipe, were it was found growing in Atlantic Forest vegetation, along the edges and interiors of forests, as well as in anthropogenically modified environments on clayey and sandy soils at elevations from 250 to $1,086 \mathrm{~m}$ elevation. Flowers and fruits were encountered from January to July.

The species is characterized by having leaves with base cordate and apex acute, and pistillate flowers with pubescent styles. Tragia friesii can be confused with $T$. bahiensis since both share glandular trichomes and dark brown seeds. They can be distinguished by the bases and apices of their leaves and the distributions of the glandular trichomes: in T. bahiensis, the leaf base is subcordate and the apex attenuate, and glandular trichomes are restricted to the reproductive parts of the plant ( vs. leaves with base cordate and apex acute, and glandular trichomes on all parts of the plant in $T$. friesii).

\subsection{Tragia volubilis L., Sp. Pl. 2: 980. 1753.}

Figure 4G-M

Climbing herbs; branches cylindrical, hirsute; with simple and urticating trichomes on the vegetative and reproductive parts of the plant; glandular trichomes absent. Stipules 2-3 mm long, lanceolate, pilose. Leaves entires; petiole $0.5-1.1 \mathrm{~cm}$ long, pubescent; blade $2-3.8 \times 1.2-1.6$ $\mathrm{cm}$, lanceolate to ovate, base subcordate to truncate, apex attenuate, abaxial surface pubescent, adaxial surface pilose. Inflorescence axillary, racemose, 2-3 cm long; bracts $0.8-1 \mathrm{~mm}$ long, narrowly elliptic, pubescent. In staminate flowers the pedicel $0.8-1 \mathrm{~mm}$ long; bracteoles ca. $0.5 \mathrm{~mm}$ long, lanceolate, pubescent; sepals $0.6-0.9 \mathrm{~mm}$ long, lanceolate, pubescent; stamens (2-)3, filaments $0.1-0.2 \mathrm{~mm}$ long. In pistillate flowers the pedicel $7-9 \mathrm{~mm}$ long; bracteoles $0.6-0.8 \mathrm{~mm}$ long, lanceolate, pubescent; sepals $0.6-0.7 \mathrm{~mm}$ long, lanceolate, pilose; ovary globose, velutinous; styles connate for half their length, glabrescent. Capsule 2-3 mm diam., pedicel $1.5-2 \mathrm{~cm}$ long, globose, pubescent, horns (3) 4-5 mm long. Seeds 1.8-2 $\mathrm{mm}$ diam., testa papillose, not variegated, light brown. 

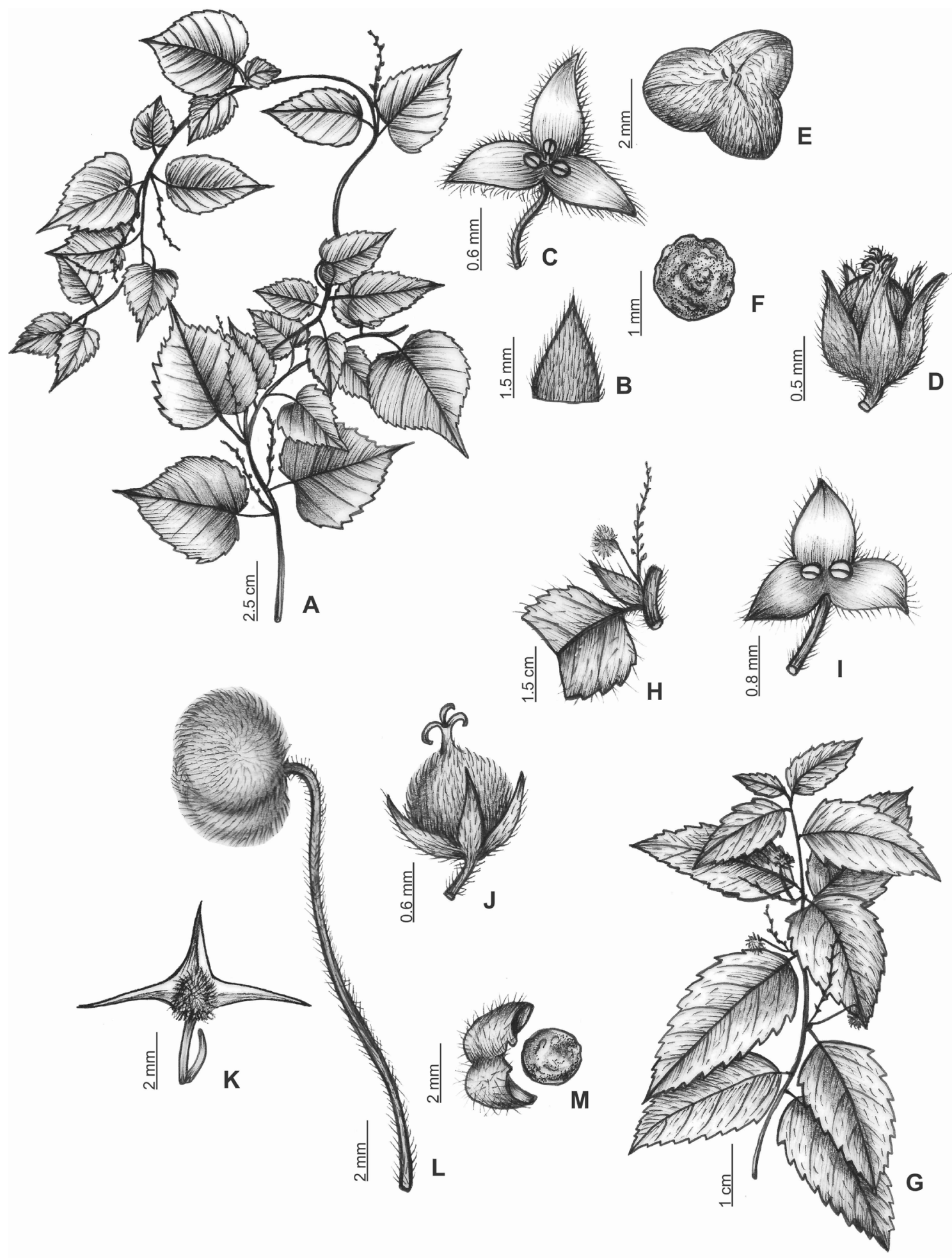

Reyim Caur tho

Figure 4. A-F: Tragia friesii (F. França et al. 2169). A: Branch. B: stipule. C: Staminate flower. D: Pistillate flower. E: Fruit. F: Seed. G-M: T. volubilis (L.P. Queiroz 5965). G: Branch. H: Bisexual inflorescence. I: Staminate flower. J: Pistillate flower. K: Fruit. L: Fruit. M: Seed. 
Material selected: BRAZIL, ALAGOAS: Pão de Açúcar, 943'24" S and 37'30'13" W, 21.VI.2002, fr., R.P. Lyra-Lemos et al. 6774 (RB). BAHIA: Pindobaçu, 1044' S and 40'21' W, 20.XII.1999, fl. and fr., M.L. Guedes et al. 6985 (ALCB). CEARÁ: Forquilha, 03 47'52' S $40^{\circ}$ and 15'39" W, 5.IV.1996, fl. and fr., A.S.F. Castro s.n. (EAC 24034). MARANHÃO: Loreto, $7^{\circ} 28^{\prime} 33^{\prime \prime} \mathrm{S}$ and $45^{\circ} 11^{\prime} 66^{\prime}$ 'W, 6.IV.1962, fl. and fr., G. Eiten \& L.T. Eiten 4107 (SP). PARAÍBA: Soledade, 705'72” S and $36^{\circ} 36^{\prime} 27^{\prime \prime} \mathrm{W}, 21$. V.2006, fl. and fr., R.F.P. Lucena 225 (PEUFR). PERNAMBUCO: Carnaubeira da Penha, $8^{\circ} 44^{\prime} 41^{\prime \prime} S$ and $38^{\circ} 75^{\prime} 52^{\prime \prime}$ W, 27.VIII.2014, fl., Costa-Lima et al. 1633 (RB). PIAUÍ: Floriano, 6 ${ }^{\circ} 76^{\prime} 69^{\prime \prime} \mathrm{S}$ and $43^{\circ} 02^{\prime} 24^{\prime \prime} \mathrm{W}, 4$. III.2005, fl. and fr., A.M. Miranda et al. 5038 (HST). RIO GRANDE DO NORTE: Tibau do Sul, 6¹4'45" S and 35'3'20" W, 2.VI.2014, fl. and fr., J.G. Jardim et al. 6661 (RB). SERGIPE: Indiaroba, $10^{\circ} 30^{\prime} 00^{\prime \prime} \mathrm{S}$ and $36^{\circ} 24^{\prime} 00^{\prime \prime} \mathrm{W}, 17 . \mathrm{IX} .2017$, fl. and fr., M.O. Santos 94 \& M.M. Costa (HUNEB).

Tragia volubilis is widely distributed and occurs throughout most of the Neotropics from Argentina to Mexico (Múlgura 1991). In Brazil, it has been cited from the states of Bahia, Rondônia, and São Paulo, being common in amazon forest and upland forests, as well as caatinga and atlantic forest vegetation (Flora do Brasil 2020 under construction). This is the first record of $T$. volubilis for the states of Alagoas, Ceará, Maranhão, Paraíba, Pernambuco, Piauí, Rio Grande do Norte, and Sergipe, where it was observed in areas of cerrado, gallery forest, and restinga vegetation, as well as in anthropogenically modified environments, growing on clayey an sandy soils, and on limestone rocks at elevations between 180 and 1,000 meters elevation. It has been found flowering and fruiting throughout the year. Among the species studied in the present work, it is the best-represented in all of the herbarium collections of Euphorbiaceae in Northeastern Brazil.

It is easily recognized by the length of the pedicel (to $2 \mathrm{~cm}$ ), which is frequently as long as the peduncle. Adictionally, the presence of monospermic fruits, with three very evident horns, as well as normal tricoccal fruits that also have small horns (although they are inconspicuous).

\section{List of collectors}

Agra, M. F. 2961 (1.7), 1964 (1.8), 2667 (1.8), 4044 (1.8). Alves, L. J. 420 (1.6), 426 (1.6). Amorim, A. M. 7694 (1.6), 4084 (1.8), 9146 (2.5), 9372 (2.5). Andrade, J. R. 96 (1.7), 172 (1.7). Andrade-Lima, A. D. 7780 (1.8). Aona, L. Y. S. 2423 (1.6), 2492 (1.6). Araújo, D. 604 (2.5), 1084 (2.2), 1465 (2.2), 4334 (2.5), 5045 (2.5), 10002 (2.5). Araújo, E. L. 445 (1.7), 437 (2.5). Araújo, F. S. 31 (1.7), 1339 (1.7). Arouck-Ferreira, J. D. C. 250 (2.5). Bacelar, T. G. 16 (1.6). Barros, A. A. M. 1757 (1.1), 2095 (1.1), 3118 (1.1). Bautista, H. P. 1220 (1.5), 1224 (2.5). Belém, R. P. 2912 (1.5). Bovini, M. G. 1771 (1.2). Brade, A. C. 12824 (2.5), 19622 (2.5). Brito, N. M. P. 78 (2.5). Brito, T. H. 4072 (1.6). Bueno, J. 14 (1.5). Calliari, C. P. 2203 (1.5). Carauta, P. 396 (1.1), 1264 (2.5). Cardoso, D. 1215 (1.8), 1702 (1.8). CarneiroTorres, D. S. 715 (2.1). Carrión, J. F. 1730 (1.4), 1731 (1.4), 1732 (1.4). Carvalho, A. M. V. 743 (1.3), 652 (1.6), 742 (1.6), 1149 (1.6), 1528 (2.5). Carvalho-Sobrinho, J. G. 130 (1.8). Castro s.n. (2.1). Cavalcanti, G. 34 (2.2). Caxambu, M. G. 1500 (2.5). Chaves, E. M. F. 163 (1.7). Conceição, S. F. 69 (2.5). Constantino, D. 1917 (1.1).
Cordeiro, J. 1132 (1.5), 1588 (1.5). Costa, E. L. 212 (1.1). Costa, K. C. 132 (1.7), 361 (1.7). Costa, M. A. A. 223 (1.3), 67 (2.5). Costa-Lima, J. L. 1633 (2.5). Couto, A. P. L. 29 (2.5). Damascena, L. 174 (2.5). Daneu, L. 238 (1.6), 532 (1.6). Dantas, R. 63 (1.7). Delgado-Júnior, G. C. 604 (2.4), 688 (2.4). Dreveck, S. 174 (1.5). Duarte, A. P. 932 (1.1), 5203 (1.2), 1766 (1.5), 5394 (2.5), 6089 (2.5). Edwall, G. E. R. F. 68 (2.3). Eiten, G. 4836 (2.3), 4107 (2.5). Falcão, J. 43 (1.5), 187 (1.5). Farág, P. R. C. 374 (1.1). Faria, G. A. 119 (2.5). Farney, C. 3603 (1.1), 3816 (1.1), 3842 (1.1), 3933 (1.1), 4119 (1.1), 4387 (1.1), 4490 (1.1). Félix, L. P. 6555 (2.2). Fernandes, A. s.n. (2.5). Fernandes, D. 233 (1.1). Ferraz, E. 39 (1.8). Ferreira, P. A. 102 (1.6). Ferreira, V. F. 2117 (2.5). Fiaschi, P. 1698 (1.3), 1715 (1.3), 2740 (1.8), 2762 (1.8). Figueiredo, M. A. s/n. (2.2). Filho, W. M. B. 6 (2.5). Fotius, G. 3823 (1.7). França, F. 2558 (1.5), 5173 (1.7), 3054 (1.8), 2169 (2.5), 2137 (2.5). Furtado, P. P. 143 (1.5). Gasper, A. L. 3133 (1.5). Geraldino, H. C. L. 311 (1.5). Giordano, L. C. 1414 (1.1). Gomes, F. S. 633 (2.5), 1005 (2.5). Guedes, M. L. 12713 (1.6), 6985 (2.5), 6895 (2.5), 9541 (2.5), 12040 (2.5), 14042 (2.5), 14186 (2.5), 14689 (2.5), 16713 (2.3), 17079 (2.5), 18355 (2.5), 19926 (2.5), 21186 (2.5). Haje, J. L. 1470 (2.5), 1710 (2.5). Harley, R. M. 55283 (1.4), 3405 (1.7), 18986 (1.7), 56379 (1.7), 16499 (2.5). Hatschbach, G. 67155 (1.5), 76822 (1.5). Hurbath, F. 526 (1.8). Jardim, A. B. 119 (1.6). Jardim, J. G. 493 (1.6), 4501 (1.8), 4750 (1.8), 6661 (2.5), 5548 (2.2). Jesus, J. A. 481 (2.5). Jesus, N. G. 920 (2.5). Kinupp, V. F. 198 (1.5). Korte, A. 6610 (1.5). Krieger, L. 7224 (2.5). Kuhlmann, J. G. 824 (2.5). Laurênio, A. 480 (1.7), 725 (1.7), 779 (1.7), 858 (1.7), 897 (1.7), 3705 (2.2). Leoni, L. S. 1122 (2.3), 2819 (2.3). Lima, A. 3068 (2.5). Lima, D. F. S. 6 (1.5). Lima, G. C. 40 (1.7), 53 (2.4). Lima, J. A. 55 (2.5). Lima, J. C. A. 261 (1.8). Lima, S. T. C. 13 (2.5). Lima, V. C. 131 (2.5), 257 (2.5). Lindeman, J. C. 1312 (1.5). Lins, A. C. B. 272 (1.7). Lisboa, M. S. 292 (2.5). Lopes, C. G. 513 (1.8). Loureiro, D. L. 525 (1.3), 763 (1.3). Lucena, D. S. 535 (2.5), 559 (2.5), 626 (2.5), 643 (2.5). Lucena, M. F. A. 803 (1.7), 1160 (1.7), 1751 (1.7), 1754 (1.7), $1186(2.4), 1315$ (2.4), 1418 (2.4), 1435 (2.4), 1468 (2.5), 1522 (2.5), 1533 (2.5), 1713 (2.2), 1833 (2.4), 1849 (2.4). Lucena, R. F. P. 225 (2.5). Lyra-Lemos, R. P. 6774 (2.5). Lyra-Lemos, R. P. 6774 (2.5). Macedo, G. E. L. 165 (2.5). Machado, A. F. P. 1136 (1.1). Machado, R. F. 539 (1.7), 149 (2.4). Maciel, J. R. 982 (1.7), 868 (2.5). Maciel-Júnior, L. 220 (1.7). Marcolino, F. 131 (2.3). Marques, M. C. 180 (1.1). Marquete, R. 481 (1.1), 2358 (1.1), 2361 (1.1), 326 (2.5). Martinelli, G. 18324 (1.8), 3129 (2.5). Martins, M. L. L. 1908 (1.8), 1910 (1.8), 1914 (1.8). Mata, M. F. 1994 (1.7), 197 (2.5). Matos, S. S. 224 (1.7). Mattos-Silva, L. A. 4020 (1.6), 4535 (1.6), 4554 (1.6), 156 (2.5). Melo, E. 5506 (1.4), 5512 (1.4), 1928 (1.7), 2088 (1.7), 4786 (1.8), 4789 (1.8), 5163 (2.5), 6270 (2.5). Melo, P. H. A. 203 (1.8), 1241 (1.8), 1373 (1.8). Melquíades, A. 51 (1.7). Menezes, L. F. T. 862 (2.5). Menezes, T. G. C. 199 (2.4). Meyer, L. M. N. 8 (1.3). Miranda, A. M. 796 (1.7), 969 (1.7), 3220 (1.7), 3649 (1.7), 6166 (2.5), 5038 (2.5). Moraes, J. C. 1155 (2.2). Nascimento L. M. 113 (1.8), 328 (1.8). Noblick, L. R. 3701 (1.7), 3111 (1.8), 3183 (1.8), 3544 (2.5). Nolasco, P. 21 (2.3). Nunes, T. S. 216 (2.2). Occhioni, P. 698 (1.2). Oliveira, A. A. 3142 (2.5), 3216 (2.5). Oliveira, M. 2790 (1.7), 3250 (1.7), 3788 (2.4), 1369 (2.5), 1753 (2.5), 2591 (2.5), 3505 (2.5). Oliveira, R. P. 532 (2.5). Paes, G. C. L. 199 (1.1). Patore, J. F. B. 5112 (2.5). Perdiz, R. O. 786 (1.6). Pereira, A. B. 173 (1.1), 174 (1.1). Pereira, E. 118 (1.1), 5357 (1.5), 7906 (2.5), 8395 (2.5). Pereira, R. S. 28 (2.3). Pessoa, L. M. 23 (1.7). 
Pickel, D. B. 2555 (1.7). Pinheiro, F. C. 158 (1.1). Pinheiro, K. 743 (2.5), 420 (2.5). Pinheiro, R. S. 1537 (1.8), 1539 (1.8). Pinto, G. C. P. 641 (1.5), 99 (1.7). Pinto, L. S. 802 (1.1). Pirani, J. R. 2973 (1.1). Platais, G. H. 15 (1.1), 4 (1.2). Plaumann, F. 437 (1.5). Popovkin, A. V. 294 (2.5). Possette, R. F. S. 510 (1.5). Queiroz, L. P. 1005 (1.8), 1007 (1.8), 12047 (1.8), 12930 (1.8), 1740 (2.5), 5798 (2.5), 5931 (2.5), 5965 (2.5), 10002 (2.5). Queiroz, R. T. 375 (1.7), 659 (1.7), 677 (2.2). Ramos, C. E. 499 (1.6), 41 (1.8). Reeves 3035 (2.1). Ribas, O. S. 6845 (1.5). Rizzon, E. 57 (1.5). Rocha, F. O. 225 (1.6). Rodal, M. J. N. 479 (2.5). Rodrigues, I. A. 41 (1.1). Roque, N. 2479 (2.5). Rosa, P. 794 (1.1), 818 (1.1), 253 (1.2). Sales, M. F. 763 (1.7), 537 (2.5), 1127 (2.5). Salino, A. 3262 (1.8), 3263 (1.8). Santos, L. L. 259 (1.7), 244 (2.5). Santos, M. O. 36 (1.7), 37 (1.7), 38 (1.7), 39 (1.7), 40 (1.7), 41 (1.7), 42 (1.7), 43 (1.7), 44 (1.7), 45 (1.7), 46 (1.7), 47 (1.7), 48 (1.7), 49 (2.4), 50 (2.4), 51 (2.4), 52 (2.4), 30 (2.5), 31 (2.5), 32 (2.5), 33 (2.5), 34 (2.5), 35 (2.5), 93 (2.5), 94 (2.5), 95 (2,5), 96 (2.5), 97 (2.5), 98 (2.5), 99 (2.5), 100 (2.5), 101 (2.5), 102 (2.5), 103 (2.5). Santos, T. S. 423 (2.5). Santos, V. J. 421 (2.5). Santos-Filho, F. S. 71 (1.7). Schinini, A. 8052 (1.5). Schwacke, P. 1875 (1.1). Shepherd, G. J. 4501 (1.6). Silva, A. A. B. 20 (2.2). Silva, A. G. 218 (1.8), 275 (1.8), 325 (1.8), 327 (1.8). Silva, K. A. 297 (1.7), 387 (1.7). Silva, L. L. 1 (1.2). Silva, M. J. 393 (1.7), 23 (1.8), 62 (1.8), 24 (2.5). Silva, P. 77 (2.5). Silva, R. A. 475 (1.7), 657 (1.7), 1431 (1.7), 807 (2.4). Silva, R. C. C. 59 (1.1). Silva, S. I. 280 (1.7), 422 (1.7), 556 (1.7), 677 (1.7). Simões, S. S. 151 (1.8). Smith, L. B. 11747 (2.5). Sobral, M. 15593 (1.5), 5845 (2.5). Souza, E. B. 3068 (1.7), 3532 (2.2). Souza, J. P. 10889 (2.2). Souza, M. A. 1208 (2.5). Strang, H. E. 470 (1.1). Sucre, D. 4459 (1.1), 5366 (1.1), 6030 (1.1), 6088 (1.1), 6186 (1.1), 7752 (1.1), 10087 (1.1), 1750 (1.2), 8517 (1.2), 4473 (2.5), 4624 (2.5), 7905 (2.5). Tessmann, G. 63 (1.5), 64 (1.5), 78 (1.5). Thomas, W. W. 11835 (1.1), 9242 (1.8). Valadão, R. M. 465 (1.3), 680 (1.3), 490 (1.6). Verdi, M. 7078 (1.8). Wasum, R. A. 3773 (1.5). Weyland-Vieira, M. C. 1639 (2.5). Xavier, A. B. 352 (2.5). Zardini, E. M. 40727 (1.5), 42561 (1.5), 49069 (2.5).

\section{Acknowledgments}

The authors would like to thank the Coordenação de Aperfeiçoamento de Pessoal de Nível Superior - CAPES for awarding a Masters fellowship to the first author; the Universidade do Estado da Bahia for financial support for translating the manuscript into English, and the preparation of the illustrations (Propublic/UNEB - Termo Outorga 06/2017); the anonymous reviewers for suggestions on the manuscript and Douglas Daly (NYBG) for English revision; all of the curators of the herbaria visited who kindly received us, as well as everyone who accompanied us and helped during the fieldwork; and Regina Carvalho for the illustrations.

\section{Author Contributions}

Mirane de Oliveira Santos: contribution to data collection, data analysis and interpretation, and manuscript preparation;

Wesley Patrício Freire de Sá Cordeiro: contribution to critical revision, adding intelectual content.

Margareth Ferreira de Sales: contribution to manuscript preparation and critical revision.
Juliana Santos Silva: contribution to manuscript preparation and critical revision, adding intelectual content.

\section{Conflicts of interest}

The author declare that they have no conflict of interest related to the publication of this manuscript.

\section{References}

APG IV. 2016. An update of the Angiosperm Phylogeny Group classification for the orders and families of flowering plants: APG IV. Bot. J. Linn. Soc. 181: $1-20$.

BARBOSA, M.R.V., SOTHERS, C., MAYO, S., GAMARRA-ROJAS, C.F.L., MESQUITA, A.C. 2006. Checklist das Plantas do Nordeste Brasileiro: angiospermas e gimnospermas. Ministério de Ciência e Tecnologia, Brasília.

CARDINAL-MCTEAGUE, W.M., GILLESPIE, L.J. 2016. Molecular phylogeny and pollen evolution of Euphorbiaceae tribe Plukenetieae. Syst. Botany 41(2): 329-347.

CARNEIRO, D.S., CORDEIRO, I., FRANÇA, F. 2002. A família Euphorbiaceae na Flora de Inselbergs da região de Milagres, Bahia, Brasil. Bol. Bot. Univ. São Paulo 20: 31-47.

CARRIÓN, J.F. Bernardia in Flora do Brasil 2020 em construção. Jardim Botânico do Rio de Janeiro. Disponível em: <http://floradobrasil.jbrj.gov. br/reflora/floradobrasil/FB54252>. Acesso in: 26 November 2018.

CARRIÓN, J.F., CORDEIRO, I., AMORIM, A.M. 2017. A new species of Bernardia (Euphorbiaceae) from the Chapada Diamantina, Bahia State, Brazil. Phytotaxa 317(1): 69-75.

CERVANTES, A. 2006. Sistemática de Bernardia sección Tyria (Euphorbiaceae). Tesis de Doctorado. Universidad Nacional Autónoma de México.

CERVANTES, A., TERRAZAS, T., HERNÁNDEZ, H. 2009. Foliar architecture and anatomy of Bernardia and other genera of Acalyphoideae (Euphorbiaceae). Brittonia 61(4): 375-391.

CORDEIRO, I. 1992. Flora da Serra do Cipó, Minas Gerais: Euphorbiaceae. Bol. Bot. Univ. São Paulo 13: 169-217.

CROIZAT, L. 1943. Novelties in American Euphorbiaceae. J. Arnold Arbor. 24: $165-189$.

FLORA DO BRASIL 2020 (under construction). Euphorbiaceae. Jardim Botânico do Rio de Janeiro.Disponível em: <http://floradobrasil.jbrj.gov. br/reflora/floradobrasil/FB113>. Access: 1 December 2017.

FORZZA, R.C. 2010. Lista de espécies Flora do Brasil. Jardim Botânico do Rio de Janeiro, Rio de Janeiro.

FOSTER, R.C. 1958. A catalogue of the ferns and flowering plants of Bolívia. Contributions from the Gray Herbarium of Havard University 184: 1-223.

GILLESPIE, L.J. 1993. Euphorbiaceae of the Guianas: annotated species checklist and key to the genera. Brittonia 45(1): 56-94.

GILLESPIE, L.J. 1994a. A new section and two new species of Tragia (Euphorbiaceae) from the Venezuelan Guayana and French Guiana. Novon 4(4): 330-338.

GILLESPIE, L.J., ARMBRUSTER, W.S. 1997. A contribution to the Guianan Flora: Dalechampia, Haematostemon, Omphalea, Pera, Plukenetia, and Tragia (Euphorbiaceae) with notes on subfamily Acalyphoideae. Smithson. Contrib. Bot. 86.

GOVAERTS, R., FRODIN, D.G., RADCLIFFE-SMITH, A. 2000. World Checklist and Bibliography of Euphorbiaceae (and Pandaceae). Kew, Royal Botanical Gardens.

HARRIS, J.G., HARRIS, M.W. 1994. Plant identification terminology: an illustrated glossary. 2 ed. Spring Lake Publishing, Spring Lake Utah.

JORGENSEN, P.M., NEE, M.H., BECK, S.G. 2014. Catálogo de las plantas vasculares de Bolívia. PhD Thesis, Missouri Botanical Garden, St. Louis.

MEDEIROS, D., SENNA-VALLE, L., ALVES, R. J. V. 2013. Revalidation of the genera Bia and Zuckertia (Euphorbiaceae) with B. capivarensis sp. nov. from Serra da Capivara, Brazil. Nordic J. Bot. 31: 595-602. 
MÚLGURA, M.E.R., SANGUINETTI, M.M.G. 1989. Actualizacion taxonomica de Tragia (Euphorbiaceae) para Argentina Y regiones limítrofes. Darwiniana 29(1-4): 77-138.

MÚLGURA, M.E.R. 1991. Sinopsis del género Tragia L. (Euphorbiaceae) del Paraguay. Candollea 46: 521-532.

MÜLLER, J.A. 1874. Euphorbiaceae. In Flora Brasiliensis: Enumeratio Plantarum in Brasilia hactenus detectarum (C.F.P. Martius \& A.G. Eichler, eds). Missouri Botanical Garden XI, part. II, p. 1-726.

OLIVEIRA, D.G. 2013. A família Euphorbiaceae Juss. em um fragmento de Caatinga em Sergipe. Scientia Plena 9(4): 1-7.

PAX, F., HOFFMANN, K. 1914. Bernardia. In: Das Pflanzenreich regni vegetabilis conspectus (A. Engler) 63-65: 21-45.

PAX, F., HOFFMANN, K. 1919. Tragia. In: Das Pflanzenreich regni vegetabilis conspectus (A. Engler) 68: 32-101.

SÁTIRO, L.N., ROQUE, N. 2008. A família Euphorbiaceae nas caatingas arenosas do médio rio São Francisco, BA, Brasil. Acta Bot. Bras. 22(1): 99-118.

SCHNEEBERGER, C.A., FARAGO, L.A. 2003. Minimanual compacto de Geografia do Brasil: teoria e prática. 1 ed. São Paulo, Rideel.

THIERS, B. 2018. [continuously updated]. Index Herbariorum: A global directory of public herbaria and associated staff. New York, New York Botanical Garden's Virtual Herbarium. http://sweetgum.nybg.org/ih/
URTECHO, R.J. 1996. A Taxonomic Study of the Mexican Species of Tragia (Euphorbiaceae). PhD Dissertation, University of California, Davis.

VIEIRA, D.A.R., VENÂNCIO, E.F., SOUZA, F.S., MOUSQUER, F. 2008. Geografia. In: IESD Brasil S.S. Curitiba.

WEBSTER, G.L., BURCH, D. 1967. Euphorbiaceae. In: Flora of Panamá. Ann. Missouri Bot. Gard. 54(1): 211-350.

WEBSTER, G.L. 1994. Synopsis of the genera and suprageneric taxa of Euphorbiaceae. Ann. Missouri Bot. Gard., vol. 81, n. 1, pp. 33-144.

WEBSTER, G.L. 2007. Taxonomic and nomenclatural changes in American Euphorbiaceae sensu lato. Contr. Univ. Michigan Herb. 25: 235-239.

WEBSTER, G.L. 2014. Euphorbiaceae. InThe families and genera of vascular plants. Volume XI. Flowering plants. Eudicots. Malpighiales. (K. Kubitzki, ed.). Springer-Verlag, Berlin Heidelberg, Germany, vol. 11, p. 51-216.

WURDACK, K.J., DAVIS, C.C. 2009. Malpighiales phylogenetics: gaining ground on one of the most recalcitrant clades in the angiosperm tree of life. Am. J. Bot. 96(8): 1551-1570.

WURDACK, K.J., HOFFMANN, P., CHASE, M.W. 2005. Molecular phylogenetic analysis of uniovulate Euphorbiaceae (Euphorbiaceae sensu stricto) using plastid $r b c L$ and $t r n L-F$ DNA sequences. Am. J. Bot. 92(8): 1397-1420. 